\title{
PERBANDINGAN EFEKTIVITAS ANTIBIOTIK GOLONGAN SEFALOSPORIN GENERASI KETIGA PADA PASIEN DEMAM TIFOID DI RUMAH SAKIT DAERAH MADANI PROVINSI SULAWESI TENGAH PERIODE 2017
}

\author{
(EFFECTIVENESS COMPARISON OF THIRD GENERATION CEPHALOSPORINS \\ ANTIBIOTIC USED IN TYPHOID FEVER PATIENTS AT MADANI REGIONAL HOSPITAL OF \\ CENTRAL SULAWESI PROVINCE PERIOD 2017)
}

\author{
RACHELIA SUNARYANI ${ }^{1 *}$, ALWIYAH MUKADDAS ${ }^{1}$, M. RINALDHI TANDAH ${ }^{1}$ \\ ${ }^{1}$ Jurusan Farmasi, FMIPA, Universitas Tadulako, Palu
}

\begin{abstract}
Abstrak: Demam tifoid merupakan penyakit sistemik akut yang disebabkan oleh infeksi bakteri Salmonella typhi. Sekitar 21 juta kasus dan 222.000 kematian terkait tifoid terjadi setiap tahun di seluruh dunia. Terapi antibiotik efektif menurunkan demam dan gejala lainnya, menurunkan mortalitas dan mencegah kekambuhan. Penelitian ini merupakan penelitian kuantitatif dengan pendekatan retrospektif untuk mengetahui antibiotik golongan sefalosporin generasi ketiga yang paling efektif terhadap pasien demam tifoid di RSD Madani Provinsi Sulawesi Tengah periode 2017, dengan menggunakan uji Kruskall-Wallis. Berdasarkan hasil penelitian disimpulkan bahwa sefotaksim lebih efektif dibandingkan sefoperazon dan seftriakson, dimana sefotaksim dapat menurunkan suhu lebih cepat (1,71 hari) dibandingkan sefoperazon (2,16 hari) dan seftriakson (2,25 hari) serta lama rawat inap lebih cepat (2,7 hari) dibandingkan sefoperazon (3,36 hari) dan seftriakson (3,92 hari) dengan nilai $p<0,05$. Sedangkan pada hari hilangnya demam tidak terdapat perbedaan yang signifikan $(p>0,05)$ terhadap ketiga antibiotik tersebut.
\end{abstract}

Kata Kunci: Antibiotik; Demam Tifoid; RSD Madani Provinsi Sulawesi Tengah

\begin{abstract}
Typhoid fever is an acute systemic disease caused by Salmonella typhi bacterial infection. About 21 million cases and 222,000 typhoid-related deaths occur every year throughout the world. Antibiotic therapy effectively reduces fever and other symptoms, decreases mortality and prevents recurrence. This research is a quantitative study with retrospective approach to find out the third generation cephalosporin antibiotics that are most effective against typhoid fever patients in Madani Hospital of Central Sulawesi Province period 2017, using the Kruskall-Wallis test. Based on the results of the study concluded that cefotaxime is more effective than cefoperazon and ceftriaxone, where cefotaxime can reduce temperature faster (1.71 days) than cefoperazon (2.16 days) and ceftriaxone (2.25 days) and length of hospitalization faster (2 7 days) than cefoperazon (3.36 days) and ceftriaxone (3.92 days) with value of $p<0.05$. While on the day of fever loss there was no significant difference $(\mathrm{p}>0.05)$ to the three antibiotics.
\end{abstract}

Keywords: Antibiotics; RSD Madani Central Sulawesi Province; Typhoid Fever

\section{PENDAHULUAN}

Jumlah kasus demam tifoid mencapai sekitar 75-80\% di sebagian besar daerah endemik (WHO, 2013). Berdasarkan data Kementrian Kesehatan Republik Indonesia tahun 2011, demam tifoid dan paratifoid menduduki peringkat ketiga penyakit terbanyak pada pasien rawat inap di Indonesia tahun 2010 yaitu sebanyak 41.081 kasus dengan angka kematian (Case Fatality Rate/CFR) sebesar $0,67 \%$.

Demam tifoid dapat terjadi akibat kontaminasi makanan atau minuman oleh bakteri Salmonella typhi secara fekal-oral. Pengobatan demam tifoid dengan antimikroba efektif menurunkan demam dan gejala lainnya dalam waktu 3 sampai 5 hari dan menuntaskan semua gejala dalam 7 sampai 10 hari, menurunkan angka kematian dari 5\% sampai $10 \%$ menjadi kurang dari $1 \%$, membatasi penyebaran infeksi, dan mencegah kambuhnya infeksi (Alldredge, 2013).

Penelitian sebelumnya yang dilakukan oleh Fithria, Damayanti, \& Fauziah (2015) dan Innesa (2013) menunjukkan bahwa pemberian antibiotik yang berbeda dapat mempengaruhi kecepatan waktu bebas panas, penurunan suhu, dan lama rawat inap pada pasien demam tifoid.

Rumah Sakit Daerah Madani Provinsi Sulawesi Tengah adalah rumah sakit rujukan Provinsi Sulawesi Tengah yang terakreditasi madya. Demam tifoid menduduki urutan ke-4 penyakit terbanyak pada pasien rawat inap umum

\footnotetext{
*email korespondensi: racheliasunaryani@yahoo.co.id
} 
di rumah sakit tersebut pada tahun 2016. Berdasarkan data dari rekam medik, jumlah pasien demam tifoid terus mengalami peningkatan dari tahun 2015 hingga tahun 2017. Adapun terapi demam tifoid di rumah sakit tersebut menggunakan beberapa antibiotik golongan sefalosporin generasi ketiga, yaitu sefotaksim, seftriakson dan sefoperazon.

Oleh karena hal tersebut peneliti tertarik untuk melakukan penelitian tentang perbandingan efektivitas antibiotik golongan sefalosporin generasi ketiga pada pasien demam tifoid di RSD Madani Provinsi Sulawesi Tengah periode 2017.

\section{METODE PENELITIAN}

Rancangan Penelitian. Penelitian ini merupakan penelitian kuantitatif dengan pendekatan secara retrospektif yang dinilai dari penggunaan antibiotik golongan sefalosporin generasi ketiga terhadap hari penurunan suhu tubuh, hari suhu kembali normal, lama rawat inap dan kondisi pasien saat keluar yang diperoleh dari data sekunder.

Populasi dan Sampel. Populasi dalam penelitian ini adalah pasien demam tifoid yang menjalani rawat inap di RSD Madani Provinsi Sulawesi Tengah periode 2017. Sampel pada penelitian ini adalah pasien demam tifoid yang menerima antibiotik golongan sefalosporin generasi ketiga di RSD Madani periode 2017 yang memenuhi kriteria inklusi dan eksklusi. Kriteria inklusi dan eksklusi sebagai berikut:

Kriteria inklusi pada penelitian ini adalah pasien rawat inap demam tifoid yang hanya menerima antibiotik golongan sefalosporin generasi ketiga tunggal; Pasien demam tifoid yang tidak terdiagnosa dengan penyakit infeksi lain dan peradangan. Kriteria ekslusif pada penelitian ini adalah pasien pulang paksa; Pasien meninggal saat pengobatan; Pasien dengan rekam medik tidak lengkap seperti hilang dan tidak jelas terbaca; serta antibiotik kombinasi.

Tabel 1. Karakteristik demografi pasien demam tifoid

\begin{tabular}{|c|c|c|c|c|c|c|c|}
\hline \multirow{3}{*}{ Jenis Kelamin } & \multirow{3}{*}{$\begin{array}{c}\text { Usia } \\
\text { (tahun) }\end{array}$} & \multicolumn{6}{|c|}{ Antibiotik $(\mathrm{n}=77)$} \\
\hline & & \multicolumn{2}{|c|}{ Sefoperazon } & \multicolumn{2}{|c|}{ Sefotaksim } & \multicolumn{2}{|c|}{ Seftriakson } \\
\hline & & $\mathbf{n}$ & $\%$ & $\mathbf{n}$ & $\%$ & $\mathbf{n}$ & $\%$ \\
\hline \multirow{3}{*}{ Laki-laki } & $15-24$ & 10 & 22,2 & 3 & 15,0 & 1 & 8,3 \\
\hline & $25-44$ & 5 & 11,1 & 3 & 15,0 & 1 & 8,3 \\
\hline & $>44$ & 1 & 2,2 & 2 & 10,0 & 0 & 0 \\
\hline \multirow{3}{*}{ Perempuan } & $15-24$ & 18 & 40,0 & 3 & 15,0 & 3 & 25,0 \\
\hline & $25-44$ & 7 & 15,6 & 7 & 35,0 & 4 & 33,3 \\
\hline & $>44$ & 4 & 8,9 & 2 & 10,0 & 3 & 25,0 \\
\hline Total & & 45 & 100 & 20 & 100 & 12 & 100 \\
\hline
\end{tabular}

Analisis Data. Analisis data dilakukan dengan metode uji non-parametrik Kruskall-Wallis menggunakan program SPSS.

\section{HASIL DAN PEMBAHASAN}

Berdasarkan penelitian yang telah dilakukan di RSD Madani, diperoleh total pasien demam tifoid rawat inap periode 2017 sebanyak 273 pasien. Dimana jumlah pasien yang memenuhi kriteria adalah 77 pasien.

\section{Karakteristik Demografi}

Data karakteristik demografi pasien sebagaimana yang ditunjukkan dalam tabel 1 menunjukkan bahwa angka kejadian demam tifoid lebih banyak terjadi pada pasien yang berjenis kelamin perempuan daripada laki-laki. Demam tifoid dapat terjadi kepada siapa saja sehingga tidak ada perbedaan terhadap laki-laki maupun perempuan. Prinsip penularan penyakit ini adalah melalui fekal-oral. Kuman berasal dari tinja atau urin penderita atau bahkan carrier (pembawa penyakit yang tidak sakit) yang masuk ke dalam tubuh manusia melalui air dan makanan (Widoyono, 2011).

Kelompok usia pasien demam tifoid berdasarkan tabel 1 menunjukkan bahwa rentang usia 15 - 24 tahun lebih mendominasi dalam penelitian ini. Rentang usia yang diperoleh ratarata pada usia remaja dan dewasa. Menurut Adiputra \& Somia (2017), pada usia tersebut lebih banyak aktivitas yang dilakukan dan juga sering berada diluar rumah, sehingga lebih mudah terinfeksi Salmonella typhi lewat mengonsumsi makanan diluar rumah yang tidak higenis.

Berdasarkan tabel 1 juga menunjukkan bahwa antibiotik golongan sefalosporin generasi ketiga yang paling banyak digunakan pasien demam tifoid rawat inap di RSD Madani periode 2017 adalah sefoperazon. Hal ini dikarenakan ketersediaannya di rumah sakit lebih banyak daripada kedua antibiotik lainnya. Sefoperazon, sefotaksim dan seftriakson menjadi pilihan dalam terapi pasien demam tifoid karena memiliki aktivitas in vitro yang baik terhadap $S$. typhi dan Salmonellae lainnya (Feasey \& Gordon, 2014). 
Tabel 2. Kadar leukosit pasien demam tifoid

\begin{tabular}{ccc}
\hline Leukosit & $\begin{array}{c}\text { Frekuensi } \\
(\mathbf{n = 7 7 )}\end{array}$ & $\begin{array}{c}\text { Persentase } \\
(\boldsymbol{\%})\end{array}$ \\
\hline Leukopenia & 3 & 3,9 \\
Normal & 49 & 63,6 \\
Leukositosis & 25 & 32,5 \\
\hline
\end{tabular}

\section{Karakteristik Klinis}

Karakteristik klinis pasien demam tifoid pada penelitian ini yaitu kadar leukosit dan profil suhu tubuh. Untuk kadar leukosit pada pasien demam tifoid di RSD Madani periode 2017 paling banyak dalam keadaan normal $(63,6 \%)$ sebagaimana yang tercantum pada tabel 2. Pada kasus demam tifoid walaupun pada pemeriksaan darah perifer lengkap sering ditemukan leukopenia, dapat pula terjadi kadar leukosit normal atau leukositosis (Sudoyo, 2009). Sebagian besar infeksi mengakibatkan peningkatan jumlah sel darah putih (leukositosis) karena mobilisasi granulosit dan / atau limfosit menghancurkan mikroba penyerang (Wells, Dipiro, Schwinghammer, \& Dipiro, 2009).

Leukopenia yang umum terdapat pada demam tifoid disebabkan oleh adanya invasi bakteri S.typhi ke organ-organ haemopoetik seperti kelenjar getah bening, spleen, tonsil, sumsum tulang belakang sehingga menekan laju haematopoesis. Bakteri ini menghasilkan endotoksin yang dapat mempengaruhi hasil dari kadar leukosit dan durasi demam pada penderita demam tifoid. Depresi sumsum tulang oleh endotoksin dan mediator endogen inilah yang mengakibatkan terjadinya leukopenia (Gayatri, 2017).

Jumlah leukosit pada demam tifoid dapat pula normal yang diakibatkan oleh patogenesis dari demam tifoid itu sendiri. Salmonella melakukan penetrasi ke lapisan mukosa usus, setelah itu S.typhi akan difagositosis oleh sel fagosit, bakteri ini justru akan bertahan di dalam sel fagosit yang dapat memberikan perlindungan bagi bakteri untuk menyebar ke seluruh tubuh dan terlindung dari antibodi serta agen-agen antimikrobial sehingga tidak terjadi respon tubuh untuk meningkatkan jumlah leukosit (Nazilah, 2013).

Berdasarkan 77 rekam medik pasien diperoleh rentang suhu tubuh pada saat awal masuk pasien (baseline) yaitu $36^{\circ} \mathrm{C}-40,5^{\circ} \mathrm{C}$. Untuk pasien yang menggunakan sefoperazon memiliki rata-rata suhu baseline sebesar $37,86^{\circ} \mathrm{C}$, rata-rata suhu turun sebesar $36,69^{\circ} \mathrm{C}$ dan rata-rata suhu hilang demam sebesar $36,50^{\circ} \mathrm{C}$. Untuk pasien yang menggunakan sefotaksim memiliki rata-rata suhu baseline sebesar $37,97^{\circ} \mathrm{C}$, rata-rata suhu turun sebesar $36,63^{\circ} \mathrm{C}$ dan rata-rata suhu hilang demam sebesar $36,42^{\circ} \mathrm{C}$. Untuk pasien yang menggunakan seftriakson memiliki rata-rata suhu baseline sebesar $37,75^{\circ} \mathrm{C}$, rata-rata suhu turun sebesar $36,52^{\circ} \mathrm{C}$ dan rata-rata suhu hilang demam sebesar $36,29^{\circ} \mathrm{C}$.

\section{Efektivitas Pengobatan}

Efektivitas pengobatan pada penelitian ini dinilai dari hari penurunan suhu tubuh, hari hilangnya demam, lama rawat inap dan kondisi pasien saat keluar. Hari penurunan suhu adalah hari dimana pasien mendapat terapi antibiotik kemudian suhu menurun, namun suhu tubuh dapat kembali meningkat. Sedangkan hari hilangnya demam adalah hari dimana suhu tubuh pasien kembali normal atau tidak kembali meningkat.

Berdasarkan tabel 3 diperoleh rata-rata hari penurunan suhu pada pasien yang menggunakan antibiotik sefoperazon yaitu 2,16 hari, pasien yang menggunakan sefotaksim diperoleh rerata 1,7 hari dan pasien yang menggunakan seftriakson diperoleh rerata 2,25 hari. Adapun uji normalitas data tersebut menggunakan Shapiro-Wilk, namun data tersebut tidak terdistribusi normal $(\mathrm{p}<0,05)$. Sehingga, digunakan uji nonparametrik yaitu uji KruskallWallis. Hasil uji Kruskall-Wallis yang diperoleh adalah nilai $p=0,023$. Hasil ini menunjukkan bahwa ada perbedaan yang signifikan, dimana hari penurunan suhu pada pasien demam tifoid yang menggunakan sefotaksim lebih cepat daripada pasien yang menggunakan sefoperazon dan seftriakson.

Tabel 3. Perbandingan hari penurunan suhu

\begin{tabular}{ccc}
\hline Obat & Rerata & $\boldsymbol{P}$ \\
\hline Sefoperazon & 2,16 & $0,023^{*}$ \\
Sefotaksim & 1,70 & \\
Seftriakson & 2,25 & \\
\hline
\end{tabular}

Ket. $p \quad$ : Probabilitas

Uji Kruskal-Wallis :

* Ada perbedaan signifikan $(<0,05)$

** Tidak ada perbedaan signifikan $(>0,05)$

Tabel 4. Perbandingan lama rawat inap

\begin{tabular}{lcc}
\hline Obat & Rerata & $P$ \\
\hline Sefoperazon & 3,36 & $0,019 *$ \\
Sefotaksim & 2,70 & \\
Seftriakson & 3,92 & \\
Ket. $p \quad$ : Probabilitas \\
Uji Kruskal-Wallis : \\
* Ada perbedaan signifikan $(<0,05)$ \\
** Tidak ada perbedaan signifikan $(>0,05)$
\end{tabular}


Untuk hari lama rawat inap seperti yang tercantum pada tabel 4 diperoleh nilai $p=0,019$ pada hasil uji Kruskall-Wallis yang berarti ada perbedaan yang signifikan antara lama rawat inap, dimana rata-rata hari lama rawat inap pada pasien yang menggunakan sefotaksim (2,70 hari) lebih cepat daripada pasien yang menggunakan sefoperazon $(3,36$ hari) dan seftriakson $(3,92)$.

Sefotaksim dikatakan lebih cepat, hal ini dikarenakan jika dilihat dari segi farmakokinetik ikatan protein dari sefotaksim memiliki ikatan protein terendah yakni $36 \%$ dibandingkan sefoperazon $82-93 \%$ dan seftriakson $85-95 \%$, yang mana jika ikatan protein tinggi maka obat yang bebas dalam darah untuk mencapai reseptor lebih rendah. Menurut Lestari dkk (2017), besar obat yang terikat protein plasma mempengaruhi distribusi obat dan kecepatan eliminasi karena hanya obat bebas yang dapat melintasi membran sel untuk dapat mencapai target obat, mengalami metabolisme dan ekskresi. Maka dari itu dengan sifat farmakokinetik sefotaksim yang memiliki ikatan proteinnya rendah menjadikan efektivitas sefotaksim lebih cepat dibandingkan sefoperazon dan seftriakson. Hal ini yang kemudian mempengaruhi penurunan suhu yang lebih cepat ataupun lama rawat inap yang paling cepat.

Hal ini didukung dengan penelitian yang dilakukan oleh Innesa (2013), dimana didapatkan data penurunan demam pada pasien dengan antibiotik sefotaksim lebih cepat yaitu dalam waktu $3,25 \pm 0,71$ hari, selanjutnya dengan kloramfenikol terjadi penurunan demam dalam waktu 4,11 $\pm 1,82$ hari dan seftriakson dalam waktu 4,71 $\pm 1,36$ hari. Namun, tidak terdapat perbedaan bermakna dalam hal kecepatan waktu penurunan demam antara antibiotik kloramfenikol, seftriakson dan sefotaksim.

Tabel 5. Perbandingan hari hilangnya demam

\begin{tabular}{ccc}
\hline Obat & Rerata & $P$ \\
\hline Sefoperazon & 2,64 & $0,402 * *$ \\
Sefotaksim & 2,45 & \\
Seftriakson & 3,00 & \\
\hline
\end{tabular}

Ket. $p \quad$ : Probabilitas

Uji Kruskal-Wallis :

* Ada perbedaan signifikan $(<0,05)$

** Tidak ada perbedaan signifikan $(>0,05)$

Berdasarkan tabel 5 yang menunjukkan perbandingan hari hilangnya demam pada pasien demam tifoid diperoleh nilai $p=0,402$ pada hasil uji Kruskall-Wallis yang berarti tidak ada perbedaan yang signifikan antara rata-rata hari hilangnya demam pada pasien yang menggunakan antibiotik sefoperazon, sefotaksim dan seftriakson. Tidak ada perbedaan yang signifikan karena rata-rata hari hilangnya demam antara pasien demam tifoid yang menggunakan sefoperazon atau sefotaksim atau seftriakson tidak jauh berbeda.

Bila dilihat dari uji sensitivitas dan resistensi $S$. typhi terhadap berbagai jenis antibiotik pada pasien demam tifoid seperti yang dilakukan oleh Alam (2011) di RSUP Dr. Hasan Sadikin, diperoleh bahwa sefoperazon, sefotaksim dan seftriakson memiliki angka resistensi yang tidak jauh berbeda, yaitu seftriakson $1 \quad(5,6 \%)$, sefotaksim 2 (1,5\%), dan sefoperazon $2(1,3 \%)$.

Untuk kondisi pasien demam tifoid saat keluar dari rumah sakit yaitu sembuh atau membaik. Dari hasil penelitian diperoleh pasien demam tifoid yang dinyatakan sembuh hanya terdapat pada pasien yang menggunakan antibiotik sefotaksim yaitu sebanyak 2 pasien (10\%). Pasien demam tifoid yang dinyatakan membaik dengan antibiotik sefoperazon sebanyak 45 pasien (100\%), yang menggunakan antibiotik sefotaksim sebanyak 18 pasien (90\%) dan pasien yang menggunakan antibiotik seftriakson sebanyak 12 pasien $(100 \%)$.

\section{Kesimpulan}

Berdasarkan hasil penelitian maka dapat ditarik kesimpulan bahwa sefotaksim lebih efektif dibandingkan sefoperazon atau seftriakson dimana terdapat perbedaan yang signifikan pada rata-rata hari penurunan suhu $(p=0,023)$ dan lama rawat inap $(p=0,019)$. Sedangkan untuk hari hilangnya demam tidak terdapat perbedaan yang signifikan $(p$ $=0,402$ ) antara ketiga antibiotik tersebut. Pasien demam tifoid yang dinyatakan sembuh hanya terdapat pada pasien yang menggunakan antibiotik sefotaksim yaitu sebanyak 2 pasien (10\%). Pasien yang dinyatakan membaik dengan antibiotik sefoperazon sebanyak 45 pasien (100\%), dengan sefotaksim sebanyak 18 pasien $(90 \%)$ dan dengan seftriakson sebanyak 12 pasien (100\%).

\section{DAFTAR PUSTAKA}

Adiputra, I. K. G. T., \& Somia, I. K. A. (2017). Karakteristik Klinis Pasien Demam Tifoid di RSUP Sanglah, m, 98-102.

Alam, A. (2011). Pola Resistensi Salmonella Enterica Serotipe Typhi, Departemen Ilmu Kesehatan Anak RSHS, Tahun 2006-2010. Sari Pediatri, 12(5), 0-5.

Alldredge, B. K. (2013). Applied Therapeutic: The clinial Use of Drugs (10th Edition). Lippincott Williams \& Wilkins. 
Feasey, N. A., Gordon, M. A. (2014). Manson's Tropical Infectious Diseases (Twentythird Edition).

Fithria, R. F., Damayanti, K., \& Fauziah, P. (2015). Perbedaan Efektivitas Antibiotik Pada Terapi Demam Tifoid Di Puskesmas Bancak Kabupaten Semarang Tahun 2014, 1-6.

Gayatri, A. A. (2017). Profil Jumlah Leukosit dan Suhu Tubuh Penderita Demam Tifoid di RSUD Karanganyar. Universitas Muhammadiyah Surakarta.

Grouzard, V., Rigal, J., \& Sutton, M. (2016). Clinical guidelines: Diagnosis and Treatment Manual For Curative Programmes In Hospitals and Dispensaries. Médecins Sans Frontières.

Innesa, C. (2013). Perbaikan Gambaran Klinis Demam Terhadap Terapi Antibiotik Pada Anak Dengan Demam Tifoid.

Kementrian Kesehatan Republik Indonesia. (2011). Profil Kesehatan Indonesia 2010. Jakarta: Kementerian Kesehatan RI.
Lestari, dkk. (2017). Buku Ajar Farmakologi Dasar. UB Press. Malang.

Nazilah, A. A. (2013). Hubungan Derajat Kepositifan TUBEX TF dengan Angka Leukosit pada Pasien Demam Tifoid Patients with Typhoid Fever, 13(3), 173180.

Sudoyo AW, Setiyohadi B, Alwi I, Simadibrata M, Setiati S. 2009. Buku Ajar Ilmu Penyakit Dalam Jilid II edisi V. Interna Publishing. Jakarta.

Wells, B. G., Dipiro, J. T., Schwinghammer, T. L., \& Dipiro, C. V. (2009). Pharmacotherapy Handbook (Sevent). United States: Mc Graw Hill Companies.

Widoyono, 2011. Penyakit Tropis: Epidemiologi. Penularan, Pencegahan dan Pemberantasannya. Edisi II. PT Gelora Aksara Pratama Penerbit Erlangga.

WHO. (2013). Guidelines on the quality, safety and efficacy of typhoid conjugate vaccines : North, (October). 